\title{
CHAPTER
}

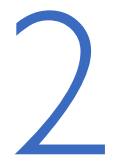

\section{Advocating for Nursing and for Health}

\author{
KAREN TOMAJAN AND DEBBIE DAWSON HATMAKER
}

\author{
Never doubt that a small group of thoughtful, committed citizens can \\ change the world; indeed, it's the only thing that ever has. \\ -Margaret Mead
}

\section{OBJECTIVES}

I. Investigate advocacy as a means to improve the safety and quality of healthcare delivery.

2. Demonstrate the competencies needed to be an advocate in different healthcare settings.

3. Describe the relationship of social justice and ethics to the work of advocacy.

4. Discuss the public's view of nursing in healthcare advocacy.

5. Identify barriers that can impact the success or failure of advocacy.

6. Select key resources to support advocacy initiatives.

In this time of unprecedented uncertainty about the future of the healthcare system lies opportunities for nurses and the nursing profession. A greater voice in healthcare policy, expanded employment opportunities, and an enhanced image for nurses and the profession are a few of the potential outcomes. Despite the opportunities afforded by being the largest healthcare group, the diversity of the scope of the nursing profession, and the unique relationship nurses share with the public, the full potential for influence is yet to be realized (Institute of Medicine, 2011; Jurns, 2019; Tomajan, 2012). After a decade of unresolved debate, the future of healthcare remains unclear. Current economic strife, political divisiveness, and social unrest compound system ineffectiveness and highlights health disparities and inequities. As the nation emerges from this difficult time, nurses must be strategically positioned to seize opportunities and leverage the forces of change in partnership with others in the evolution of healthcare.

The evolution of modern nursing began in the late 1800s as Florence Nightingale published her views about how nurses should be educated and patient care should be provided (Hegge, 2011). Although Nightingale did not directly use the word advocacy in her writings, her works were consistently about advocating for change (Selanders \& Crane, 2012). Her own words speak to the importance she placed on action and change: "I think one's feelings waste themselves in words; they ought all to be distilled into actions and into actions which bring results" (Cook, 1913, p. 94).

Since the inception of the profession, nurses have been actively involved in advocacy and activism on behalf of patients, families, communities, and patient populations and have worked tirelessly to address healthcare and social justice issues that impact health. The concept of advocacy is part of professional nursing. Advocacy involves a complex interaction among nurses, patients, professional colleagues, and the public at large (Selanders \& Crane, 2012). To be an effective 
Linda Minnich RN, BSN, Nurse Clinician, is a staff nurse on the postoperative recovery unit in a community hospital. She attended a pain management conference and was inspired to bring what she had learned back to improve care for patients in her work setting. She was aware of the impact of postoperative pain, and the detrimental effects of sustained opioid use. Linda was a member the shared governance council that provided a forum for collaboration with nurses from other hospital units and found universal interest in new practice innovations to improve patient experiences of pain and discomfort.

Linda had some ideas which included focusing on orthopedic surgery patients, a high-volume population for her hospital. She was ready to advocate for patients but didn't quite know how to begin. She sought assistance from her hospital's director of professional practice to help her determine how she could best apply what she had learned.

She was looking for answers to questions such as:

- What is the most effective way to advocate for culture change in various nursing units?

- What is the organization's philosophy about advocating for culture change?

- Which competencies are needed to be an advocate?

- What resources are available within the work setting to facilitate new procedures?

- What advocacy organizations will be helpful in promoting these changes?

- What standards, guidelines, or best practices are available to provide evidence-based support to the advocacy process?

nursing professional, a nurse must understand and embrace the role of advocateadvocating for health and for the nursing profession.

This chapter provides an overview of the concept of advocacy, the nurse's advocacy roles, and expectations of society and the profession regarding advocacy. The American Nurses Association's (ANA, 2015) Code of Ethics for Nurses is used as a framework to describe the application of advocacy. In addition, competencies for advocacy, resources for becoming an advocate, and advocacy arenas are identified. Advocacy exemplars are used to illustrate the various possible outcomes of nurses' advocacy efforts. See the Policy Challenge, which describes how a nurse was inspired to improve the care of patients experiencing pain after attending a pain management conference. She worked within the organization to introduce new pain management modalities, train the staff, and influence hospital policy development.

\section{ADVOCACY DEFINITIONS}

Advocacy is defined as "the act or process of pleading, supporting, or recommending a cause or course of action. Advocacy may be for persons (whether an individual, group, population or society) or for an issue such as potable water or global health" (ANA, 2015, p. 41). Advocacy can take many forms and may require working through formal decision-making bodies to achieve positive results. This could include working through committees, an administrative chain of command, state commission, regulatory body, or state/federal legislative entity.

The term advocacy was first included in the profession's codes by the International Council of Nurses (ICN) in 1973 (Vaartio \& Leino-Kilpi, 2005). Nursing education 
documents prior to the mid-1970s did not reference advocacy as a clear expectation in nursing. In fact, early nursing education historically emphasized conformity, obedience, and subservience (Selanders \& Crane, 2012). Since that time, advocacy has increasingly been associated with the role of the professional nurse. This evolution of nursing practice from loyalty to advocacy has put forward a metaphor of the nurse as an advocate of patients' rights, which has been readily embraced by nurses. In recent years, there has been an ever-increasing mandate for the profession's further evolution to encompass a broader social justice advocacy model while retaining individual commitment to patient-nurse advocacy. This has been a challenging transition that continues to evolve today (Florell, 2020; Paquin, 2011). As U.S. healthcare moves to a more socially just system, it is important that nurses leverage their sizable political clout to help drive this change. As the largest and most trusted professional group, nurses are expected to actively lead with a social justice mindset. This requires the ability to push "nursing advocacy to move beyond the bedside and outside the walls of the institutions in which most nurses work" (Paquin, 2011, p. 67).

In a review of empirical literature from 1990 to 2003, Vaartio and Leino-Kilpi (2005) identified three themes related to patient advocacy: advocacy motivated by the patient's right to information and self-determination, advocacy stemming from the patient's right to personal safety, and advocacy as a philosophical principle in nursing. Bu and Jezewski (2007) discuss three core attributes of nursing advocacy: safeguarding patient autonomy, acting on behalf of patients who are not able to act for themselves, and championing social justice.

In recent years, increased focus on patient safety and continuity of care has helped spotlight the vital role nurses play in every setting to ensure patients receive safe, effective care and their rights are protected. Nurses have played a key role in the evolution of healthcare, with the recognition that there is a more expansive role for the profession that could and should be realized.

While nurses readily accept the requirement of the professional nurses' advocacy role as it applies to their patients; advocacy activities that extend to broader groups or for global issues are less consistently evident. Two of the ANA's core documents, the Code of Ethics for Nurses with Interpretive Statements (ANA, 2015) and Nursing: Scope and Standards of Practice (ANA, 2021), delineate the professional nurse's responsibility to advocate at multiple levels: nurse-patient, nurse-nurse, nurse-self, nurse-others, nurse-profession, nurse-society, and nursing-society (Bazdak \& Turner, 2015).

The ANA's (2021) Nursing: Scope and Standards of Practice clearly identifies "advocacy" within the scope of nursing practice, suggesting that it is fundamental to practice, and identifies four levels of advocacy:

n Individual: The nurse educates healthcare consumers to consider actions, interventions, or choices related to their own personal beliefs, attitudes, and knowledge to achieve desired outcomes.

- Interpersonal: The nurse empowers healthcare consumers by providing emotional support, assistance in attaining resources, and necessary health through interactions with families and significant others in social support networks.

- Organization and community: The nurse supports the cultural and social transformation of organizations, communities, or populations and helps inform environmental and societal conditions related to health, wellness, and care of the healthcare consumer.

- Policy: The nurse promotes the inclusion of the healthcare consumer's voices into policy, legislation, and regulation about such issues as access, cost reductions, and protection of the healthcare consumer and the environment. 
The ANA's (2015) Code of Ethics for Nurses with Interpretive Statements (2015) identifies multiple advocacy expectations for the professional nurse. These expectations include a commitment to patients, families, communities, and populations served. Nurses also have an obligation to advocate for the profession through teaching, mentoring, peer review, involvement in professional associations, community service, and knowledge development and dissemination. These activities and skills are foundational to the advocacy role of the professional nurse.

Advocacy is based on a foundation of ethical principles that include autonomy, beneficence, nonmaleficence, fidelity, and justice. It is essential that advocates act in the interest of those they represent in the advocacy process and align their actions with these principles (ANA, 2015; Butts \& Rich, 2016):

- Autonomy: Autonomy is respect for another's right to self-determine a course of action and support for independent decision-making. Nurses should protect the autonomy of those for whom they are acting, which includes involvement in decision-making.

n- Beneficence: Beneficence is acting to help others and to protect them from harm. The desire to "do good" and help others is a core principle of advocacy.

nonmaleficence: Nonmaleficence is the avoidance of harm or hurt. This principle is sometimes described as "do no harm" and is likewise an important role of the advocate.

- Fidelity: Keeping one's promises and being truthful and loyal to those represented are unequivocal expectations of the advocate. Disclosing personal interests and being cognizant of one's own goals prevent conflict of interest when advocating on behalf of others.

- Justice: Justice is a "moral concept of fairness and equality ... [and includes] treating people equally, without prejudice and equitable distribution of benefits and burdens" (Butts \& Rich 2016, p. 46.).

\section{CODE OF ETHICS FOR NURSES}

Advocacy carries with it a significant ethical dimension; therefore, principles of ethics can help to evaluate a nurse's effectiveness as an advocate. A code of ethics is fundamental for any profession. It provides ethical and legal guidance to the members of the profession, as well as a social contract with the population served. ANA published its original Code of Ethics (www.nursingworld.org/codeofethics) in 1950. Through seven revisions, the code "retains nursing's historical and ethical values, obligations, ideals and commitments" (Fowler, 2015, p. ix). Several significant changes have occurred since the Code's original publication: (a) the conceptualization of "patient" has expanded from that of an individual receiving treatment to include the family, community, and population; (b) a provision that recognizes the nurse's responsibilities for self-care; and (c) emphasis on social justice, health as a universal right, and a responsibility to advocate for global health issues such as poverty, violence, and oppression (Fowler, 2015). Each of the nine code provisions includes an aspect of advocacy.

\section{PROVISION I}

The nurse practices with compassion and respect for the inherent dignity, worth, and unique attributes of every person (ANA, 20I5, p. I).

Respect for inherent dignity, worth, unique attributes, and human rights are fundamental to nursing practice. Nurses establish relationships based on trust and free from bias or prejudice. Factors such as culture, values, religious or spiritual beliefs, lifestyle, social support system, sexual orientation or gender expression, 
and primary language must be considered when planning care. Nurses provide the same level of care regardless of diagnosis, ethnicity, or economic status. Therefore, the nurse is ethically bound to care and advocate for all. The nurse supports the patient's autonomy and self-determination, including informed consent, by providing accurate, complete, and understandable information that supports the patient's decision-making process. This obligation of respect for others extends to all individuals with whom the nurse interacts and defines the nurses' responsibility to create an ethical environment and culture of civility.

\section{PROVISION I EXEMPLAR: Right to Self-Determination}

Richard James is 87 years old and a resident in an assisted living center. He is single; however, he has a very close family with seven nieces and nephews in the area. Six months ago, while living in his own home, he experienced a small stroke that left him with memory and balance deficits. Since admission to assisted living, his condition has improved. He has decided that he is going to go back to his own home. His oldest niece, Lydia Grant, is his healthcare proxy and executor of his estate. Mr. James's entire family is very concerned about his safety at home. Lydia talks with the director of nursing, Sylvia Sanchez, seeking her opinion about Mr. James's ability to manage his home situation, particularly related to safety. Nurse Sanchez points out that Mr. James has steadily improved over the months he has been in the facility and reminds his niece that the decision to return home is ultimately Mr. James's. Nurse Sanchez sets up a care conference with the facility physician, social worker, Lydia, and Mr. James. Based on the discussions, Mr. James will have home health assistance and a part-time housekeeper to assist him several days per week with cooking, shopping, and transportation for errands and medical appointments. Nurse Sanchez works with Lydia to coordinate his move out of the facility. In addition, Nurse Sanchez reassures Mr. James that he can return to the facility if his condition changes.

\section{PROVISION 2}

The nurse's primary commitment is to the patient, whether an individual, family, group, community, or population (ANA, 20I5, p. 5).

Ethical dilemmas arise as the nurse attempts to balance a commitment to the patient, the family, and the community; however, this provision is clear that the nurse's primary obligation is to the patient. "Nurses address such conflicts in ways that ensure patient safety, guard the patient's best interests, and preserve the professional integrity of the nurse" (ANA, 2015, p. 5). Interpretation of this provision speaks to distributive justice when resources are limited, collaboration when caring for a patient in the complexity of the healthcare environment, and professional boundaries within the nurse-patient relationship. Therefore, advocacy has its limits and limitations that must be observed.

\section{PROVISION 2 EXEMPLAR: Commitment to the Patient}

Karen Anderson, $R N$, works in the role of patient relations liaison. She receives a telephone call from Rachel Carr, who had been cared for earlier that day in the ED for back pain. Ms. Carr was quite upset, saying that during the visit the physician had been rude, called her a "drug seeker," and did not offer any pain-relief treatment or medication. Ms. Carr explained that she has a chronic back injury had just moved to the area and reinjured her back while unpacking boxes. Although she has a future appointment with a local physician, she has not yet been seen, and the physician's staff referred her to the ED. Nurse Anderson meets with the ED nurse manager and medical director and arranges for Ms. Carr to be reevaluated later that day. 


\section{PROVISION 3}

The nurse promotes, advocates for, and protects the rights, health, and safety of the patient (ANA, 20I5, p. 9).

Provision 3 addresses the patient's right to privacy and confidentiality, safeguarding research participants, and addressing incompetent practice (whether it involves impairment or lack of knowledge or skill). "The nurse has a duty to maintain confidentiality of all patient information, both personal and clinical in the work setting and off duty in all venues including social media or other means of communication" (ANA, 2015, p. 9). The nurse must always weigh the patient's right to privacy with protecting the patient from harm. Provision 3 outlines the nurse's role in promoting a culture of safety, which includes responsibilities for reporting errors and near misses and for addressing the problem of incompetent practice. Whether the incompetence is due to impairment or a lack of knowledge, the nurse must report the issue to the appropriate person in the organization. If not acted on, the nurse must then take the next step in the organizational hierarchy or even consider reporting to an outside accrediting or regulatory body. Such advocacy skills as maintaining standards of care, advocating for impaired colleagues, or whistle-blowing may come into play with this provision.

\section{PROVISION 3 EXEMPLAR: Addressing Impaired Practice}

John Smith, RN, has just completed his first year of practice on the telemetry unit. His nurse preceptor, Linda Nelson, has been a great support during his orientation, and he is feeling very confident as he enters his second year. Linda has recently separated from her husband of 20 years and has not seemed herself lately. John notices that she is arriving late for work, looks strained, and is disorganized. Linda has verbally blown up while interacting with several coworkers in the past week. He noticed alcohol on her breath the past 2 days that she has come to work, and he is really concerned about Linda and her patients. When John identifies that Linda almost administered an incorrect medication-a "nearmiss" error-he realizes he must take his concerns to their nurse manager. Ethically, he is bound to address his colleague's impaired practice and ensure the safety of patients.

\section{PROVISION 4}

The nurse has authority, accountability, and responsibility for nursing practice; makes decisions; and takes action consistent with the obligation to promote health and provide optimal care (ANA, 20I5, p. I5).

Accountability for actions is the cornerstone of a profession due to the implied social contract with the public. Nursing has been identified repeatedly as the most honest and ethical profession because its practitioners take the issue of accountability seriously. This accountability includes self-assessing competency, seeking educational resources when less than competent to perform care, and delegating appropriately to other healthcare providers. This provision highlights the need for nurses' acceptance of accountability and self-assessment to be effective advocates.

\section{PROVISION 4 EXEMPLAR: Accountability for Nursing Judgment and Action}

Stacy Samuels, RN, a faculty member, who teaches pediatric nursing in a baccalaureate nursing program, works per diem in the summer on the pediatric or mother-baby units of a community hospital. One Saturday, she reports to the pediatric unit only to learn she has been assigned to float to the sixth-floor adult oncology unit due to low pediatric census. Nurse Samuels has never been oriented to any of the adult units and has not taken care of adult oncology patients since she graduated from nursing school 10 years ago. She does 
not feel safe in providing nursing care to oncology patients. She calls the house supervisor; however, the call has not yet been returned. She reports to the sixth-floor nurses' station and tells the charge nurse that she will agree only to take patient vital signs and do patient personal care. When the supervisor makes rounds, Stacy intends to inform her that she cannot ethically take accountability for complete care of these patients since she does not have the knowledge, competence, and experience to engage safely in their care.

\section{PROVISION 5}

The nurse owes the same duties to self as to others, including the responsibility to promote health and safety, preserve wholeness of character and integrity, maintain competence, and continue personal and professional growth (ANA, 2015, p. 19).

Provision 5 addresses moral self-respect, professional growth, and the maintenance of competence, wholeness of character, or integration of personal and professional values. Self-advocacy is inherent in this provision. Nurses should model health promotion and maintenance, including rest, diet, exercise, healthy relationships, and work/life balance. Nurses may face threats to integrity when confronted with verbal threats or abuse from patients, families, or coworkers. Preservation of nurses' integrity under this provision would also allow for the concept of "conscientious objection" when a treatment, intervention, or activity is morally objectionable to the nurse. Although nurses cannot abandon their patients, they must make it known to the administration when situations place them in moral dilemmas that they find objectionable (Lachman, 2015).

\section{PROVISION 5 EXEMPLAR: Wholeness of Character}

Patsy Williams is a 56-year-old patient diagnosed with stage IV metastatic breast cancer and is on an aggressive chemotherapeutic regimen. She is experiencing extreme nausea and anorexia unresolved by medications. Her goals are to spend quality time with her family and friends and to continue to teach third grade as long as possible. Leah Donnelley, RN, is an oncology nurse in the freestanding outpatient oncology center caring for Patsy. Patsy asks Nurse Donnelley's opinion of medical marijuana to alleviate

POLICY ON THE SCENE 2.I: ARIZONA NURSES ADVOCATING FOR HEALTH AND SAFETY

Dedicated staff nurses Jasmine Bhatti, Jade Juriansz, Laruen Leander, and Brittiany Schilling demonstrated public health advocacy when they learned that a rally was planned at the Arizona State Capitol for individuals protesting the governor's stay-at-home orders and other COVID-19 pandemic mitigation measures. They joined others at the Capitol and stood in defense of public health and the safety of colleagues doing everything possible to save lives. Photos of the nurses went viral and became a flashpoint in the national debate (Ruelas, 2020).

After the media attention subsided, the nurses used their notoriety to help raise money for underserved communities hit hardest by COVID-19. In May, they helped launch the Navajo and Hopi Community Relief Fund via the online platform GoFundMe. The effort raised over \$287,000 for the Navajo and Hopi people. These donations helped support critical COVID relief efforts, purchasing food, water, personal protective equipment (PPE), medical supplies, and other relief for families and healthcare workers in these communities (Navajo-Hopi Observer, 2020). As a result of her work, Lauren Leander received a John F. Kennedy Profile in Courage Award in November 2020 (John F. Kennedy Presidential Library, 2021). 
her nausea symptoms. Patsy has explored this option on the internet and brings her informed questions to Nurse Donnelley. Patsy asks for help in exploring this modality. Although medical marijuana is approved for use in this state, Nurse Donnelley personally opposes the use of marijuana under any circumstances. However, Nurse Donnelley is an experienced RN and knows that while she could voice her opinion, ethically she should assist Ms. Williams in clarifying her own values in reaching an informed decision, thus avoiding unintentionally persuading her one way or another. Nurse Donnelley agrees to investigate the latest evidence on the effectiveness of cannabis for chemotherapy-induced nausea. She also calls a team conference with Ms. Williams, her oncologist, and the center's dietitian and pharmacist to formulate a comprehensive plan to address Ms. Williams's nausea and to help her determine if and how she might best make use of this modality.

\section{PROVISION 6}

The nurse, through individual and collective effort, establishes, maintains, and improves the ethical environment of the work setting and conditions of employment that are conducive to safe, quality healthcare (ANA, 20 I5, p. 23).

Provision 6 extends the nurse's obligation to advocate for an ethical work environment that supports the values central to nursing. The reciprocal relationship between the nurse and the work environment is inherent in this provision. The work environment can either obstruct or support nursing values and ethical obligations. This provision sets forward an expectation of moral activism; the nurse should work to change the environment if it is obstructive. The goal is for nurses to work with the administration to create an environment that supports safety and quality patient care (Lachman, 2015; Lachman et al., 2015). Advocacy on a large scale is possible when nurses join with their professional associations and participate in collective action such as workforce advocacy, collective bargaining or legislative days (see Figure 2.1). When this is not possible and an organization refuses to support patient rights or puts nurses in a position that violates professional standards of practice, nurses may have little choice but to leave the organization.

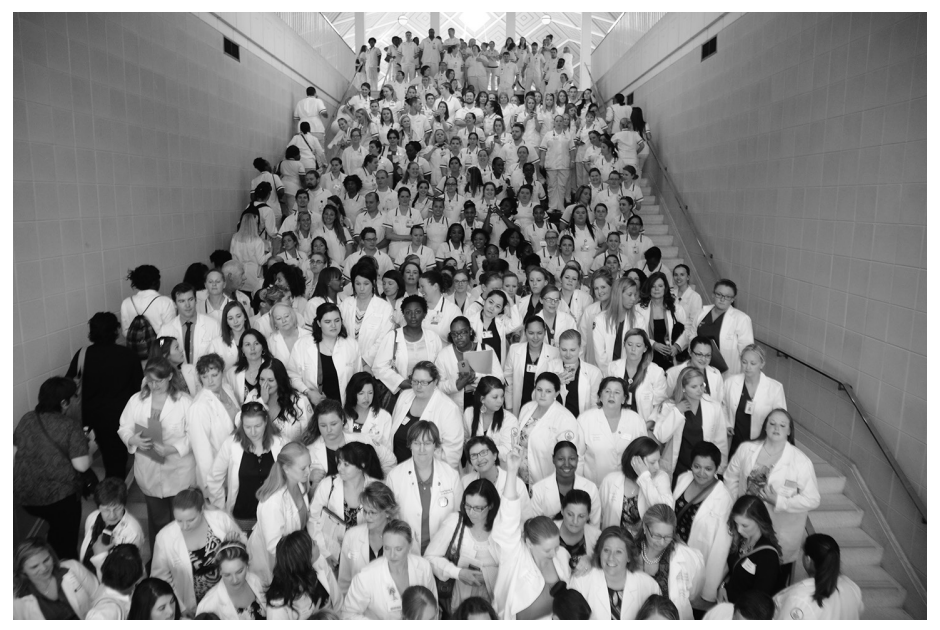

FIGURE 2.I North Carolina Nurses Association Capitol Hill Day Source: Reproduced with permission from the North Carolina Nurses Association. 


\section{PROVISION 6 EXEMPLAR: Improving the Healthcare Environment}

Patricia Brown is a staff nurse in a critical care unit. She is very committed to her colleagues and believes that maintaining a healthy work environment is the responsibility of every nurse. She overhears Angela Nelson, one of her colleagues, speaking condescendingly to a new nurse who has asked a question regarding the unit routine. After the conversation concludes, Patricia pulls Angela aside and relates what she heard between the two nurses. She shares her feelings that Angela was too harsh with the new nurse and relays her concern that this is an example of incivility. She informs Angela that harsh communication with new staff is detrimental to the development of a positive unit environment and relays her belief that every staff member should feel comfortable asking questions of any colleague without fear of reprisal. Patricia discusses the situation with her manager who supports her actions and offers to intervene if there are further issues.

\section{PROVISION 7}

The nurse, in all roles and settings, advances the profession through research and scholarly inquiry, professional standards development, and the generation of both nursing and health policy (ANA, 20 I 5, p. 27 ).

Advancement of and advocacy for the nursing profession is the focus of this provision. Many activities are representative of this obligation: mentorship, service on organizational shared governance committees, leadership in professional associations, and civic activity at the local, state, national, or international levels. Nurses contribute through knowledge development, research and scholarly inquiry, development and enactment of professional standards, and participation in nursing and health policy development. Nurses advocate through role-specific responsibilities that include the nurse educator's responsibility for nursing education standards, the nurse researcher's support of clinical practice by providing practice-based evidence, and nurse administrators' advocacy in creating environments that support the ethical integrity of staff.

\section{PROVISION 7 EXEMPLAR: Advancing the Profession}

State nurses associations routinely review new bills being presented in state legislatures to determine the impact on the health of citizens as well as the impact on the profession. A bill has been forwarded to the state legislature that allows clerical staff in public schools to administer medications to students. The association's legislative committee believes that passing this bill could compromise the safety of school children and that a better alternative would be to increase funding to hire more school nurses across the state. They partner with school nurses and involve their specialty organization, the National School Nurses Association, to jointly lobby against this bill in the legislature, citing the potential risks to children.

\section{PROVISION 8}

The nurse collaborates with other health professionals and the public to protect human rights, promote health diplomacy, and reduce health disparities (ANA, 20I5, p. 3I).

Provision 8 addresses advocacy for health concerns in the larger world, calling on nurses to advance health and human rights and to reduce disparities. This provision identifies health as a universal right, which includes access to healthcare, basic sanitation, potable water, food security, immunizations, injury prevention, 
and health promotion. Nurses are called to collaborate with others to bring attention to human rights violations such as poverty, abuse, rape, hate crimes, genocide, human trafficking, and exploitation and to address the needs of special populations such as the homeless, mentally ill, and elderly. This provision also addresses situations in which nurses are required to practice under extreme conditions, such as during disasters, epidemics, and fields of battle.

\section{PROVISION 8 EXEMPLAR: Raising Awareness of Health Disparities}

Ernest Grant, PhD, RN, FAAN, was elected president of the American Nurses Association from 2018 to 2022. His area of practice is burn nursing, and he is well known nationally and internationally as an educator on burn care and prevention. Dr. Grant is the first male president of the ANA, and is also the first African American male to serve as the president of the North Carolina Nurses Association. In 2020, Dr. Grant participated in a COVID-19 Phase III vaccine trial at the University of North Carolina. Because the virus was disproportionately affecting communities of color, he felt compelled to participate in the trials, to assure there was enough evidence to determine the vaccine's efficacy in these populations. He also felt he could serve as an influencer to encourage people of color to take the vaccine if they knew individuals who look like them participated safely in the trial. Dr. Grant served as a role model to encourage nurses and other health providers to get vaccinated when the national program launched.

\section{PROVISION 9}

The profession of nursing, collectively through its professional organizations, must articulate nursing values, maintain the integrity of the profession, and integrate the principles of social justice into nursing and health policy (ANA, 20I5, p. 35).

Who advocates for the nursing profession? The focus of Provision 9 is on the profession through its associations rather than the individual nurse. It calls for nurses associations and organizations to act collectively with one voice, in

\section{POLICY ON THE SCENE 2.2: USE OF TRUSTED INFLUENCERS}

\section{IN ADVOCACY INITIATIVES}

At the outset of the COVID-19 pandemic, morbidity and mortality statistics indicated significant disproportionate levels of severe complications and death among members of the Black, Latinx, and Native American populations. Surveys also indicated that these same populations held deep-seated distrust of the healthcare system, based on legitimate historical experiences, particularly as it related to vaccines and other "experimental" therapies. In planning for the COVID-19 vaccine distribution, one key concern was that these patient populations would not accept the vaccine. Plans for distribution of the newly developed COVID-19 vaccines were targeted for early administration to members of these communities to stop transmission of this deadly pathogen. However, this presented an ethical dilemma. Given the requirements for storing and distributing the vaccine vials, it was essential to act rapidly to increase the trust and willingness of these groups to be vaccinated. With the help of the Ad Council, a not-for-profit foundation with expertise in formulating population-specific ads, a vaccination communication plan was developed and implemented in a matter of days. One key strategy was to involve "trusted influencers" from within these communities in the planning process. Trusted influencers included religious leaders-pastors, priests, medicine men, and shamans - as well as physicians, nurses, athletes, pop stars, and political 
leaders in a tailored communication strategy designed with the input of each target group. This resulted in a higher level of vaccination than would otherwise have been expected. The ANA was one of 18 partner organizations that contributed to videos highlighting the importance of COVID-19 vaccination. ANA President Ernest J. Grant, PhD, RN, FAAN contributed the following statement in association with this initiative:

I am grateful for the courage and dedication of those on the frontlines of the pandemic. I was proud to participate in a COVID-19 vaccine clinical trial as a way to demonstrate my confidence in the safety and efficacy of the development process and in this Ad Council initiative to reach nurses and physicians with timely and important information. I encourage nurses to be informed and to get vaccinated as soon as possible, to protect themselves and as a role model for others, so that we can achieve widespread vaccination and return to normal activities.

solidarity across all specialties, roles, and practice settings to articulate nursing values, maintain the integrity of the profession, and integrate the principles of social justice to reduce health disparities. The integrity of the profession is based on the covenant between nursing and society through a code of ethics, standards of nursing practice, and educational requirements for practice, knowledge development, and continuing evaluation of professional nursing actions. A specific focus on social ethics reflects nursing's historical interest in how health and illness affect society.

\section{PROVISION 9 EXEMPLAR: Articulating Nursing Values and Maintaining Professional Integrity}

Following the devastating hurricanes in Louisiana, Mississippi, Florida, and Texas in 2006, the ANA acted, along with other professional associations and regulatory agencies, to define the responsibilities of nurses and other healthcare professionals in disaster situations. The ANA worked with state and national agencies and disaster-relief organizations such as the American Red Cross to define the role of the RN in a disaster, establish structures to coordinate disaster response through the Medical Reserve Corps, and define potential legal protections for nurses acting in good faith in catastrophic situations (ANA, 2017). These actions are examples of the association's advocacy for nursing as a profession, which impacts all nurses, not just ANA members.

This laid the groundwork to facilitate the responses of nurses in subsequent disasters. The ANA's collaboration among state nurses associations, nursing specialty organizations, allied health groups, governmental and public service organizations provided a useful network that was activated to efficiently and effectively advocate for healthcare professionals during recent disasters, particularly the COVID-19 pandemic.

\section{CLINICAL PRACTICE AND MORAL DISTRESS: THE REALITY OF PRACTICE ADVOCACY}

Nurses in clinical practice encounter ethical issues that can lead to moral distressnegative feelings that result when one knows the ethically correct action to take 
but feels powerless to take that action (ANA, 2015; ANA Professional Issues Panel, n.d.; Rushton, 2017, Rushton et al, 2017). For nurses to be effective advocates, they must understand and accept their ethical responsibilities to the patient, family, community, and profession. However, when nurses are unable to advocate due to practice barriers, fear, or lack of skills-moral distress ensues. Moral distress results in psychological distress and feelings of anxiety, irritability, frustration, anger, fatigue, or depression. When left unchecked, moral distress undermines safety and quality of care, disrupts interprofessional relationships, contributes to burnout, stress disorders, and results in turnover and the loss of nurses from the profession (Rushton, 2017). Causes of moral distress include conflict between the nurse's responsibility to the patient and duty to the employer; a lack of colleague support; perceived a lack of power; fear of reprisal from colleagues, physician, or supervisor; inadequate resources to meet patient needs; and a lack of education or skills. When surveyed, nurses have identified ethical priorities that include the following (Pavlish et al., 2011):

- Patients' Quality of Life: an obligation to treat distressing symptoms, pain, or suffering.

- Promoting Patient Autonomy: the notion that patient preferences should prevail over family wishes or healthcare team values.

- Substandard Healthcare: situations in which the healthcare team either did not adhere to standards of care, were severely conflicted over treatment options, or had inadequate resources to provide the usual standard of care.

Many healthcare agencies have processes and policies that establish the chain of command to address ethical concerns, which may include an ethics committee tasked with addressing ethical dilemmas. Nurses increasingly have a voice in advocating for their patients within these organizations. However, these processes are often inadequate.

New approaches to assist nurses and other healthcare professionals to cope with the impact of moral distress and to promote the development of moral resilience are being implemented. Moral resilience is the ability to recover from or healthfully adapt to the challenges of stress, adversity, or trauma and to be "buoyant" in the event of adverse circumstances. Interventions for cultivating moral resilience include mindful meditation, cognitive reappraisal, biofeedback, and organizational support such as ethics rounds, debriefings, and consultations. Educational strategies include training on ethical principles and decision-making, conflict resolution, change management, mindfulness, spiritual well-being, and self-care (ANA, n.d.; Rushton, 2017; Rushton et al., 2017).

\section{SOCIAL JUSTICE}

Social justice is defined as the belief in equality for all people, including the distribution of the advantages and disadvantages among the individuals in a society (Butts \& Rich, 2016). A strong commitment to social justice requires professional nurses to advocate for the health of all persons. Advocacy activities are an expected outcome for a health profession that promotes the concept of social justice. Social justice advocacy is an inherent expectation of all nurses as expressed in the professional codes that guide nursing practice (ANA, 2015; Paquin, 2011).

Nursing has long maintained a strong commitment to advocacy for vulnerable populations and has embraced social justice as a core value since the inception 
of the profession. Early nursing leaders were strong advocates for the healthcare needs of the vulnerable and disadvantaged. In recent years, the profession has been called on to reinvigorate its commitment to social justice advocacy and to build on nursing's distinguished history of leadership on social issues (Florell, 2020; Matwick \& Woodgate, 2016; Valderama-Wallace, 2017).

\section{EQUITY}

An important role of the advocate is to promote equity and eliminate or mitigate the effects of health disparity at both theindividual and system levels. One of the features of healthcare reform has been to address disparities and promote equity within the healthcare system. Health equity "means that everyone has a fair and just opportunity to be as healthy as possible. This requires removing obstacles to health such as poverty, discrimination and their consequences including powerlessness and lack of access to good jobs with fair pay; quality education and housing; safe environments; and healthcare" (Braveman et al., 2017, p. 2). Health disparity is defined as the differences in health outcomes attributed to inequities in healthcare delivery (Butts \& Rich, 2016). Disparities contribute to infant mortality, disability, decreased life expectancy, and higher incidence of preventable hospitalizations (Braveman et al., 2017; see Chapter 13).

As a profession, nurses have led the way among healthcare professionals in their work to promote a healthcare system that is accessible to all and to address issues of disparity and inequality. In the advocacy role, nurses have worked to address the equity needs of individual patients and patient populations and to advance health policy at the healthcare system level.

\section{DISCRIMINATION AND RACISM}

Contributors to health inequity and social injustice are discrimination and racism. Discrimination exists when a person is treated unfavorably or unjustly according to a particular characteristic such as race, age, gender, or religion (ANA, 2018). Racism is a complex term that includes prejudice, bias, and discrimination directed toward an individual or group based on membership in a particular racial or ethnic group, typically one that is a minority or marginalized. Racism also exists across systems, institutions, and societies resulting in practices that disadvantage minority populations (Annie E. Casey Foundation, 2020).

"Racism is a public health crisis that impacts the mental, spiritual and physical health of all individuals. The Code of Ethics for Nurses obligates nurses to be allies and advocates and speak up against racism, discrimination and injustice" (ANA, 2020, para. 2). In the weeks and months following the 2020 deaths of George Floyd and Breonna Taylor, citizens including nurses and other healthcare professionals took to the streets to protest, calling for law enforcement reform and changes in public policy to end racism. In June 2020, the ANA's Membership Assembly adopted the "Resolution on Racial Justice for Communities of Color," which reaffirmed previous positions on discrimination and condemned law enforcement cruelty and abject racism. The resolution also sought to advance institutional and legislative policies that promote diversity, equity, inclusion, and social justice for all. The ANA (2020) established a collaborative among nursing organizations to further develop education and advocacy actions to end systematic racism at the state and national levels. 


\section{PUBLIC EXPECTATION FOR ADVOCACY}

You are traveling in a foreign country where you do not know the culture or language. How will you get your needs met? You may use nonverbal cues like gestures or pictures, but you are not certain you will be understood. What if you had an advocate, someone who knows the language, culture, and belief system? The U.S. healthcare system is foreign and challenging for many patients. There are technical terms, abbreviations, jargon, and euphemisms that complicate communication. Hospitals have hierarchies, policies, standards, routines, and rituals that are mysterious to patients, families, visitors, and students (Bosek \& Savage, 2007).

The public has come to expect nurses to serve in the role of advocate, assisting them to migrate through the "foreignness" of the healthcare system. Although no single profession "owns" the role of advocate, nursing has traditionally seen this role as integral to good nursing care. The American public also sees the nurse in the role of advocate in that they have rated RNs as the most honest and ethical profession for the past 19 years, according to Gallup's annual survey (Saad, 2020). Nurses are increasingly recognized as leaders in transforming the healthcare system to meet the burgeoning demand for services, with a focus on improving quality and managing costs. In a 2019 survey conducted by the New York Times, Commonwealth Fund, and Harvard T. H. Chan School of Public Health, respondents rated nurses' recommendations for healthcare system redesign as the most trusted, over that of doctors, hospitals, or the government (Rappleye, 2019).

Although the public has come to know nurses' advocacy activities through their patient care experiences, they do not always see nurses in key leadership roles. A 2010 Gallup poll of 1,500 health opinion leaders indicated they wanted nurses to have more influence in a variety of areas: reducing medical errors, increasing quality of care, and promoting wellness. They also believed that nurses should have more influence in policy development (Khoury et al., 2011). However, in contrast, an American Hospital Association survey of 1,000 U.S. hospitals found that nurses accounted for only $6 \%$ of hospital board members. This contrasts with the number of physicians (20\%) and other clinicians (about 5\%) on boards (Van Dyke et al., 2011). In 2014, the Robert Wood Johnson Foundation and the Center to Champion Nursing in America formed the Nurses on Boards Coalition (NOBC). A goal for adding 10,000 nurses to boards of directors by 2020 was established, resulting in a threefold increase in the number of board appointments in a 4-year time frame. Nurses bring a unique perspective to boards, panels, and commissions in their understanding of health needs across the care continuum and the issues of frontline healthcare providers. They also bring critical thinking, active listening, communication, and change management skills (Harper \& Benson, 2019). The NOBC announced at the end of 2020 the goal had been achieved with more than 10,035 nurses appointed to a variety of decision-making boards.

\section{COMPETENCIES NEEDED TO BE AN ADVOCATE}

Two of ANA's foundational documents, the Code of Ethics for Nurses with Interpretive Statements (2015) and Nursing: Scope and Standards of Practice (2021), address the professional nurse's responsibilities for advocacy. The documents cover the required competencies and activities of professional nurses, through the care of patients, teaching, mentoring, peer review, involvement 
in professional associations, community service, and knowledge development and dissemination. The skills of problem-solving, communication, influence, collaboration, and resource identification are also useful to support a cause on behalf of a patient, a family, a community, a population, the profession, or oneself (Tomajan, 2012).

\section{Problem-Solving}

Since advocacy is directed at problems in need of a solution, the problem-solving process is a necessary skill for the effective nurse advocate. The steps in problem-solving and strategies to achieve each are illustrated in Figure 2.2.

This problem-solving process should feel very familiar to nurses, as it parallels the steps in the nursing process. Figure 2.2 provides guideposts for planning and implementing advocacy efforts. Getting Help (under "Analyze the problem") is important and should occur early in the advocacy process. Novice advocates are advised to seek advice from trusted colleagues, supervisors, or mentors who know the organization and the decision-making process. Their perspective of the current state and appropriate timing will be invaluable to the development of a successful action plan.

\section{Communication}

Communication is key to an effective advocacy strategy. Verbal, written, and electronic forms of communication are used when advocates pull individuals together to work collectively on a problem. It is important that all messages are based on

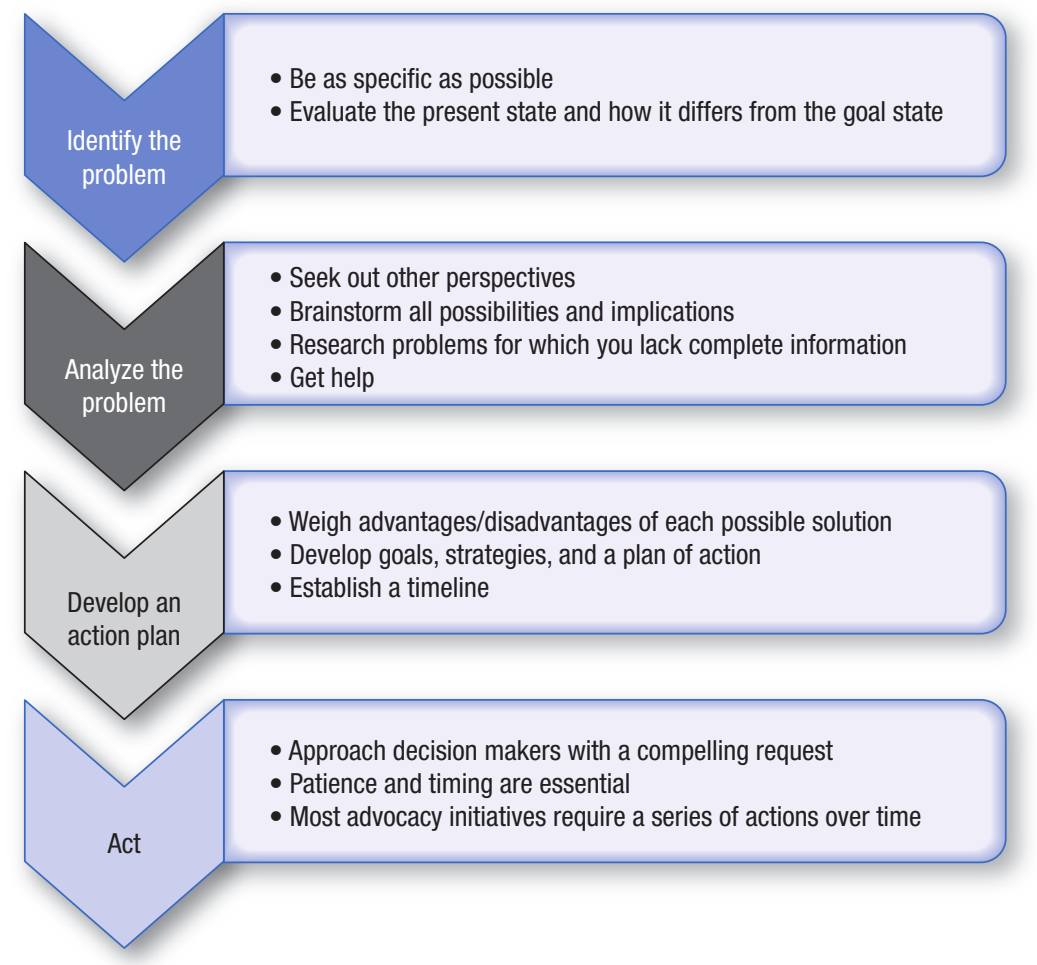

FIGURE 2.2 Problem-solving process. 
fact and that messaging across time is consistent. Although advocates are often "armed" with facts and figures when they attempt to influence decisions-makers, it is equally important to tell the story of the impact of the problem, particularly as it affects people. Giving specific examples of patient care situations or how individuals within the community are affected by an issue (without violating privacy) can demonstrate how the problem and suggested solution(s) have a real-world impact.

\section{Influence}

To be effective, the nurse advocate must be able to influence others. Influencing an individual or group's thoughts, beliefs, or actions is essential and built on competence, credibility, and trustworthiness (Tomajan, 2012). Advocates use influence to effect change in a number of ways. Access to decision-makers may be gained through strategies such as telephone calls, town hall meetings, face-to-face interactions, letter-writing campaigns, legislative testimony, financial contributions, or joining organizations with missions that align with the advocacy initiative.

Using an influential leader or spokesperson can bring attention to an issue. Celebrities, such as Michael J. Fox for Parkinson's disease research and Marlo Thomas for cancer in children, are regularly tapped to bring their influence on important issues. An influencer may also be a leader or influential member of a target group asked to promote an issue or solution. An influencer may be able to reach groups whose trust level with the advocate is low. To influence most effectively, the advocate must build a compelling case for change by using facts, figures, and examples. Equally important, the advocate must be able to influence others with a strong delivery. Developing an "elevator speech" is a valuable tool for the advocacy toolkit (see Table 2.1; see also Chapter 10). Written materials distributed in association with an elevator speech should be brief, succinct, and align with the verbal presentation. A one-page bulleted document is highly recommended, with the request being made stated clearly. Contact information for follow-up should be included.

\section{TAB LE 2.I: Key Elements of a Good Elevator Speech}

\section{FOLLOW THESE GUIDELINES WHEN PREPARING AN ELEVATOR SPEECH:}

Keep It Short: After hearing a few sentences, your audience should know what you do and what you want. Limit your pitch to 60 seconds.

- Have a "Grabber": An opening line that grabs the person's attention and piques interest in hearing more.

Show Your Passion: Your energy and dedication will help sell your proposal.

Make a Request: At the end of your speech, mention what you need. Do you want that person's business card? Do you want to schedule a meeting? Ask for a referral? Getting the person to take the next step is crucial. It is the reason you came up with your speech in the first place.

Practice: Rehearse your elevator speech so that when the opportunity to use it comes up, you can do it well. Always be prepared to give your pitch so you can use it in a chance encounter. Memorize it. Revise as needed to keep it fresh and updated.

Source: Reprinted with permission. Copyright (C2021, HealthCom Media. All rights reserved.

Adapted from Pagana, K. D. (20 I3). Ride to the top with a good elevator speech. American Nurse Today, 8(3), I4-16. https://www.americannursetoday.com/ride-to-the-top-with-a-good-elevator-speech 


\section{Collaboration}

In the complex world of healthcare, few changes are made in isolation. In fact, advocacy should be considered a team sport. Collaboration and partnership are necessary to effect major change. Collaboration is a process of working with others for a common purpose. Collaborative ventures involve the development of common goals, strategies, and activities that will achieve those goals (Tomajan, 2012). Successful collaboration can be a time-intensive process requiring ongoing communication with those involved, validating information, and reporting on progress toward the goal. The ANA, in collaboration with the Association of Nurse Executives (AONE now known as the American Organization for Nursing Leadership [AONL]), developed Principles for Collaborative Relationships to guide nurses in communicating with supervisors, and leaders within and outside the workplace (ANA/AONE, n.d.).

When collaborations are developed, it is helpful to consider all possible stakeholders to strengthen the advocacy efforts. Nurses may partner with other nurses or nursing organizations when the issue is directly related to professional nursing practice, but collaboration with other healthcare providers or even community-based groups can strengthen the advocacy efforts and message. An example of a coalition designed to address issues for advanced practice nurses and other healthcare providers is the Coalition for Patients' Rights (CPR). This coalition consists of 14 healthcare organizations working to offset the efforts of the American Medical Association's Scope of Practice Partnership (SOPP) initiative that was developed to limit patients' choices of healthcare practitioners. The CPR is predicated on the principle of patients having the right to choose their type of provider and having access to the right type of care at the right time (www.patientsrightscoalition.org).

\section{Resource Identification}

Another important skill for the nurse advocate is the ability to identify valuable resources. Although this competency is necessary for any problem-solving process, searching for health information is an essential skill when it comes to advocacy (White et al., 2010). Searching the internet for resources is commonplace; however, with the explosion of web-based information, much of it lacking credibility validation, the task can be daunting. Steps to a successful health policy internet search are illustrated in Figure 2.3.

Credible resources on the internet that the nurse advocate should use include peer-reviewed and professional databases (e.g., PubMed, the Cumulative Index to Nursing and Allied Health Literature), professional associations (e.g., ANA, the American Association of Critical-Care Nurses [AACN]), health policy organizations (e.g., the Robert Wood Johnson Foundation [RWJF], the Kaiser Family Foundation), and governmental entities (e.g., the Centers for Medicare \& Medicaid Services [CMS], the Centers for Disease Control and Prevention). The

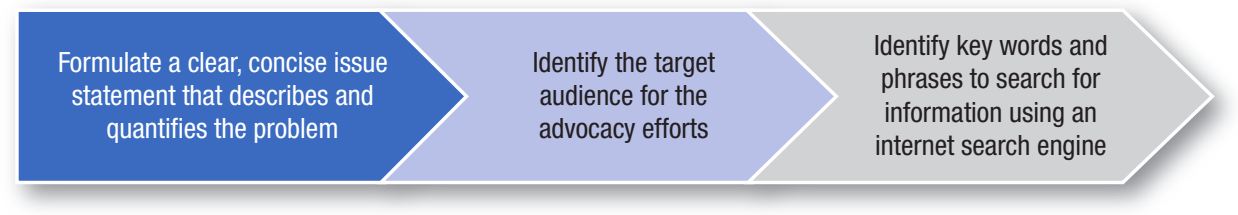

FIGURE 2.3 Steps for successful health policy searches on the internet. 
following criteria are suggested for evaluating websites for use in advocacy activities (Binghamton University, 2020; White et al., 2010):

- Accuracy and Expertise: The qualifications, affiliations, and reputations of the authors are vital for reliability and credibility. Attention to details, especially in relation to scholarly references, is a hallmark of quality.

n Content and Focus: The website should be examined for a complete, balanced, and unbiased presentation of information. Reputable websites often include a mission statement, are clear about their perspective and intended audience, and include contact information.

1. Currency: The information should be recent unless it is of historical nature. Broken uniform resource locator (URL) links and websites without recent update information indicate a poorly maintained website and raise questions about credibility.

- Organization and Ease of Use: Navigation should be user-friendly. The information may have limited use if the web pages, documents, and portable document format (PDF) files do not load easily and quickly. Member-based organizations often place valuable information behind a "For Members Only" section.

Extra care to ensure information accuracy is essential. Given the environment of fake news, alternate facts, and the myriad of misinformation available on the internet, it is incumbent on the nurse advocate to validate the accuracy and currency of information. Misinformation is false or inaccurate information that may be the result of mistakes or misunderstanding, whereas disinformation is false information intended to mislead or even cause harm (Binghamton University, 2020). Nurses should be members of their professional associations and other groups that support their advocacy work to get the most current and complete information (see Chapter 10).

\section{ARENAS FOR ADVOCACY}

Nurses have numerous opportunities for advocacy. The one that most often comes to mind is the workplace; however, advocacy also occurs in the community, state, national, and global arenas.

\section{Workplace}

Nurses most frequently use their advocacy skills in the workplace-whether it is a hospital, public health clinic, long-term care facility, or primary care office. Advocacy works best in environments that encourage its activity, where leaders are supportive, and where tools are available to make change happen.

The work environment of nurses has been studied extensively, with strong links to patient and nurse outcomes. Factors that define the work environment include workload, staffing, managerial support at the unit and organizational level, work team dynamics, and interprofessional relationships. The work environment impacts patient outcomes, including the patient experience, the incidence of infections, falls, pressure injuries, and mortality. Nurse-focused outcomes that are the result of work environment factors include job satisfaction, turnover, exhaustion and burnout, and perceptions of quality of care (Lake et al., 2019; Press Ganey, 2015).

The AACN (2016) developed the AACN Standards for Establishing and Sustaining Healthy Work Environments that address not only the physical environment but also fewer tangible barriers to staff and patient safety. The AACN highlights the ingredients for success as skilled communication, true collaboration, effective decision-making, appropriate staffing, meaningful recognition, and authentic 
leadership. These standards are guidelines that the nurse as advocate can use to support a healthy work environment. Mounting evidence is making the connection between positive work environments and patient and nurse outcomes (Lake et al., 2019; Press Ganey, 2015).

In 2017, the ANA launched the Healthy Nurse Healthy Nation (HNHN) initiative to address health issues of nurses. On all measures other than smoking, nurses are less healthy than the general population. The HNHN's vision is to "improve the nation's health one nurse at a time." The initiative involves partnership with multiple organizations to improve nurses' health in five domains-physical activity, nutrition, rest, quality of life, and safety; and provides online resources to support nurses' self-care goals. In 2020, strategies were added to address financial health. In 2020, more than 183,000 nurses were participating in opportunities for self-advocacy and role modeling for patients (HNHN, 2020).

Along with its partners and through its organizational relationships, ANA is a leader in promoting improved work environments. It protects, defends, and educates nurses about their rights as employees by addressing occupational hazards such as needle stick safety, back injuries, and workplace violence. The ANA and specialty organizations have developed a number of position statements and resources to support advocacy in the workplace. These resources are available at www.nursingworld.org/practice-policy/nursing-excellence/official-positionstatements/.

\section{Community}

When nurses are advocating in their community for increased access to care or other healthcare resources, the respect they have from the public strengthens their ability to persuade others to create the needed changes regarding patient care and services. The cost of healthcare continues to create barriers for patients. Patients and families often share with the nurse the difficulties they are experiencing in obtaining needed care due to the costs of treatments and medications. Nurses find themselves advocating at the individual and community levels on access issues and funding to address the patients' ability to receive appropriate healthcare services. Nurses have been engaged in identifying community resources for patients and establishing resources when they are inadequate. Because of the high expense of prescription drugs, many patients forego treatment when they do not have the funds to obtain needed medication. Nurses may be aware of community resources for drug discounts or even pharmaceutical companies' resources to obtain needed treatment. Nurses have established community-based clinics for those who do not have adequate access to healthcare. These nurse-managed health centers under the direction of APRNs provide primary, secondary, and tertiary prevention services to the uninsured and underinsured populations; there are more than 200 such centers across the country (Holt et al., 2014; Valdez, 2017).

\section{State}

Although nurses may feel comfortable taking on the advocate role within their workplace or community, they may hesitate to take it to the next level and use their advocacy skills at the state level. They may not feel confident about their presentation skills or believe that others know more about the issue than they do (Jurns, 2019). However, they quickly find that their passion and healthcare knowledge will take them far in state advocacy. The ANA represents the interest of over 4.3 million RNs across the United States through its constituent and state nurses 
associations and its specialty nursing and affiliate organizations. With the implementation of the Patient Protection and Affordable Care Act, more commonly known as the ACA, and the ongoing state-level scope of practice issues that are barriers to APRNs, there is much to be done at the state level. One important provision of the ACA that highlights the need for effective state and national partnerships was the establishment of state insurance exchanges. These exchanges-online marketplaces where individuals can purchase health planshave been established at the state level. The ANA works with the CMS to use language that includes APRNs to ensure that patients have improved access to care. With the continuing debate about healthcare reform, this collaboration is even more important to ensure that these gains continue within the structures of any new or revised legislation passed by Congress. Most barriers to APRN practice are at the state level as the result of state laws and regulations, including each

\section{POLICY ON THE SCENE 2.3: REMOVING SCOPE OF PRACTICE BARRIERS}

In September 2017, Elizabeth Ellis, DNP, RN, APRN, FNP-BC, FAANP, CRHCP, opened the B.I.S. Community Clinic in rural Bedias, Texas. The B.I.S. Clinic is a CMS-designated Rural Health Clinic that serves Bedias, Iola, Singleton, and surrounding communities. One of the many challenges that Elizabeth encountered was the inconvenience and strain of having to drive 2 hours to meet face-to-face monthly with her collaborative physician as a requirement of her nurse practitioner prescriptive authority agreement (PAA). This requirement took her away from the only healthcare facility in northern Grimes County.

Just 2 months prior to the opening of B.I.S Community Clinic, the Texas legislature passed Senate Bill 1625 with an amendment allowing physicians assistants to meet virtually with their supervising physicians in place of a face-to-face meeting. Unfortunately, APRNs were not included in this bill. Frustrated with the disparity, as well as the significant time and travel demands the outdated mandate imposed on her and her delegating physician, Elizabeth worked with members of the APRN Alliance to get the legislation changed. The APRN Alliance is a partnership of Texas APRN organizations that represent certified nurse-midwives, nurse anesthetists, clinical nurse specialists, nurse practitioners, and the Texas Nurses Association (TNA). The APRN Alliance met as an informal collaborative to improve the APRN practice environment in Texas. The alliance coordinates the efforts and communication between the organizations to sure consistent messaging.

Leading the APRN Alliance on this issue were TNA staff members who utilized their relationship with Representative Tom Oliverson to argue that this was not the best use of the APRN's or physician's time, especially when they have telemedicine capability. Representative Oliverson agreed and introduced House Bill 278. On February 27, 2019, Elizabeth testified on behalf of the bill. The proposed legislation passed unanimously through both the House (141-0) and Senate (31-0) and was signed into law on May 16, 2019. This example demonstrates the value of coalitions, unity, and speaking with one voice, which requires good communication and maximizing the talent and resources of each member.

State nurses associations and state-based coalitions have been vital to moving advocacy and lobbying activities and educating nurses to take on the additional responsibilities that are required at this level. State lobby days are one of the many activities held to educate nurses about important practice issues and ways they can make a difference when speaking to legislators, mayors, city council members, community activists, or the public at large. 
state's respective nurse practice act. It is vital for nurses to advocate within their state for removing practice barriers such as requirements for physician supervision and prescriptive authority restrictions.

\section{National}

Moving advocacy to the national level typically takes nurses from their familiar practice settings to the unfamiliar world of policy and politics, a world in which many nurses do not feel prepared to effectively maneuver. Successful policy advocacy requires one to have the power, will, time, and energy, along with the political skills needed to "play the game" in the legislative arena. This move into national advocacy is challenging and time-consuming but offers the nurse a unique opportunity to make a difference in patient care and the satisfaction of playing a role in improving the healthcare system.

Many nurses who are active in the national arena honed their skills first through experiences with policy and legislative events sponsored by their state nurses association. Policy fellowships and workshops can also provide the needed opportunities to learn more about healthcare issues and the legislative process (see the Section "E-Resources"). There are multiple ways to get actively involved: Write a letter or email, make a call to your representative in Congress, attend a state or national Lobby Day event, educate your colleagues on national aspects of health policy such as healthcare reform, or even run for elective office. There are currently several nurses serving in the U.S. House of Representatives.

Many complex health policy issues require collaboration and sustained efforts to effect and maintain change. Organized nursing groups, the assistance of professional lobbyists, and sustained activity for months or even years are required when issues are as complex as healthcare reform or changing models of care delivery. Nurses who participate in their state and national nurses associations have access to important resources and can strategize collaboratively to bring nursing's perspective to legislative or regulatory decision-makers. Professional nursing organizations, such as the ANA, monitor public policy as their core work and educate their members about the impact of policy issues. This is illustrated by the ANA's collaborative work conducted over many years in support of healthcare reform.

\section{Global}

Advocacy on the global stage seems quite daunting. The ICN leads the profession in these efforts, representing the interests of nearly 28 million nurses worldwide. ICN seeks to align and integrate nursing actions around global health priorities and to influence the World Health Organization (WHO) and other decision-making bodies to shape health policy at the global level. The ICN publishes and disseminates position statements and educates nurses and the public at large about key health issues. The ICN advocates for policies that contribute to social justice, global health, sustainable development, and just treatment of nurses and healthcare professionals.

The ICN and other international health agencies have worked for many years to ban nuclear weapons. In 2021, an updated position statement was published by the International Committee of the Red Cross, ICN, International Federation of Medical Student Associations, International Physicians for the Prevention of Nuclear War, World Federation of Public Health Associations and World Medical Association that defines the threat and supports international efforts to ban 
nuclear weapons (ICN, 2021). In 2016, the ICN took its Leadership for Change ${ }^{\mathrm{TM}}$ (LFC) program to China to develop stronger nursing leaders at the national level. The LFC program is now established in more than 40 countries and focuses on the development of nursing knowledge and leadership skills. As a federation of more than 130 national nurses associations, the ICN works to effect global change (ICN, 2016) (see Chapter 14).

In 2018, the WHO created a new position, chief nursing Officer, and appointed Elizabeth Iro, a public health nurse and midwife from the Cook Islands (McSpendon, 2018). Ms. Iro has the opportunity to give voice to nearly 28 million nurses from around the world. In 2020, the WHO and the ICN published the State of the World's Nursing: Investing in Education, Jobs and Leadership, outlining the challenges and opportunities related to the global nursing workforce. The WHO, in collaboration with the ICN, designated 2020-2021 as Year of the Nurse and Midwife to commemorate the 200th anniversary of Florence Nightingale's birth and provide a platform to bring attention to the many contributions of nurses worldwide.

Increasingly, social and healthcare issues are global as opposed to simply national or regional. Global health issues transcend national boundaries and involve complex interagency and interprofessional cooperation for planning, prevention, and response. Solutions that respect health equity among nations often involve governments, nonprofits, and many times corporations and foundations. Examples of global issues include emerging infectious diseases including pandemics, human trafficking, maternal-newborn mortality, climate change, food insecurity, and hunger. These issues are influenced by the worldwide maldistribution of healthcare professionals (Edmonson et al., 2017).

Nurses across the globe are focused on the concept of advocacy as they provide care to their patients. Scandinavian nurse researchers examined how advocacy is defined by patients and nurses (Vaartio et al., 2006). Turkish nurses studied how ICU nurses make decisions about the distribution of scarce beds to their patients (Ersoy \& Akpinar, 2010), and Iranian nurses developed their own patients' bill of rights and code of ethics while studying the extent of involvement in patient advocacy among their country's nurses (Negarandeh \& Dehghan Nayeri, 2012; Salehi et al., 2010). The newly revised ICN Code of Ethics for Nurses (ICN, 2021, p. 7) indicates that nurses "advocate for equity and social justice in resource allocation, access to healthcare and other social and economic services."

\section{WHEN ADVOCACY FAILS/WHEN ADVOCACY SUCCEEDS}

One needs only to review the case example of U.S. healthcare reform to understand the arduous and complex nature of advocacy. From President Theodore Roosevelt's efforts toward national health insurance in the early 20th century to the creation of Medicare and Medicaid under President Johnson in 1965 and finally to the 2010 passage of the ACA under President Obama, the advocacy efforts of more than 100 years have brought us many improved programs but with many challenges left unresolved.

If advocacy is such an important aspect of nursing care, why do efforts sometimes fail? What are the barriers that prevent nurses from being effective advocates on behalf of their patients, themselves, or their profession? In a concept analysis of barriers to nursing advocacy, Hanks (2007) identified the most common barriers as conflict of interest between the nurse's responsibility to the patient and the nurse's duty to the employer, a lack of support, lack of power, time constraints, threats of 
punishment, the nurse's lack of education, and the historical barrier of being in a feminine profession with a tradition of subservience to the medical profession.

Institutional barriers to advocacy are challenging and often difficult to address. Nurses must know the legal scope of practice in their state and in their healthcare facility. Knowing the statutes and regulations assists nurses in being more effective advocates. If more assistance is needed with the state nurse practice act or practice guidelines, nurses should contact their state nurses associations; however, it is important for nurses to understand that membership organizations can best support only those dues-paying members who contribute to their profession.

Clear, effective communication is central to overcoming advocacy barriers. The nurse's ideas and suggestions are more effective when spoken clearly and without overt emotion such as anger and frustration. Even body language makes a difference. Using a loud voice, leaning into another person's space, pointing fingers, or crossing arms conveys hostility and prevents the nurse's message from being received. Patient-centered language is the best approach when seeking to be an effective advocate. Written documentation may also prove important if the situation escalates or there are negative patient outcomes.

The nurse must understand and use the employer's chain of command. There are important organizational policies for reporting concerns and issues that arise. The employer may have an administrative structure that includes committees supporting advocacy efforts (e.g., ethics, shared governance, staffing).

Education has a major role to play in teaching effective advocacy. Faculty must teach the issues related to nursing advocacy, as well as role model what it means to be an advocate - at the individual patient level and the political/policy level. The practicing nurse should seek a preceptor, mentor, or sponsor who demonstrates strong advocacy skills to assist in navigating difficult clinical issues and organizational processes. The following advocacy exemplars illustrate the range of issues, the forms an advocacy effort might take, and the different outcomes for the advocacy efforts.

\section{Advocacy Exemplar: Understaffing}

Labor and delivery nurse Mary Washington was tired, frustrated, and worried-her unit had been dealing with high census and low staffing for many months. The staff nurses were concerned for a while and had met with the unit manager to voice their concerns. Mary had even presented her professional organization's staffing guidelines to nursing leadership in an effort to make the case for improved staffing. However, it seemed that cost constraints were not allowing new staff to be hired, and Mary knew it was just a matter of time before understaffing would cause a problem. Some signs of fetal distress might be missed, and then a negative outcome would throw light on the consequences of the unit's staffing patterns. She was just a few years out of her undergraduate program, so Mary consulted with one of her maternal-child health faculty members, who gave her suggestions for advocacy efforts. She also consulted with her state nurses association to see if there were any regulations or other guidelines that might apply. She took all the suggestions to her unit manager and division director to advocate for safe patient care and protection of her own practice. Ultimately, Mary realized that she was being labeled a "troublemaker," so after discussing the situation with her colleagues, she determined she had no recourse but to resign and take a position at a different hospital in the city with safer staffing levels.

\section{Advocacy Exemplar: Removing Scope of Practice Barriers}

The value of APRNs is increasingly recognized by policymakers and consumers. As nursing practice is regulated by state boards of nursing, the United States continues to have 
a jumble of different regulations across state boundaries. However, a shift to full practice authority for APRNs is taking hold across the country as a result of nurses associations' advocacy and consumers' demand for better access to primary care providers. States are continuing to pass legislation to allow full practice authority for nurse practitioners (see Chapter 1).

\section{Advocacy Exemplar: The Whistle-Blowing Nurses From Winkler County, Texas} In 2009, two nurses, Anne Mitchell and Vickilyn Galle, anonymously reported Dr. Rolando Arafiles Jr. to the Texas Medical Board for unsafe care. Dr. Arafiles urged the county sheriff and county attorney to uncover who made the report and then struck back at the nurses who were charged with misuse of official information, a third-degree felony, and fired from their jobs. After their case was nationally publicized by the TNA and the ANA, $D r$. Arafiles's attempts to retaliate against the two whistle-blower nurses were uncovered. Subsequently, Dr. Arafiles was charged with misuse of official information and retaliation, also a third-degree felony. He was sentenced to 60 days in jail and fined \$5,000. Three others involved in the case received jail sentences and lost their jobs as a result of the roles they played: Sheriff Robert Roberts Jr., Attorney Scott Tidwell, and Hospital Administrator Stan Wiley. Nurses Mitchell and Galle were completely exonerated and received a civil suit settlement of $\$ 375,000$.

\section{ADVOCACY ORGANIZATIONS}

Nurses advocate to support patient autonomy and rights; however, they are less effective when challenging problems such as inadequate staffing or patient access to care unless they collectively respond to such systemic issues. Within direct-care clinical situations, individual nurses are staunch patient advocates, yet this focus of patient advocacy overlooks systemic problems that can cause harm to all patients (Florell, 2020). Although patient advocacy is most often framed in terms of an obligation to individual patients, it must include social and political advocacy and activism to address the full spectrum of patient care issues. Collective activism for nurses is best accomplished through professional associations. For professional nurses associations to effectively advocate for their professionals, they must rely on their members to report instances of inadequate and substandard care, as well as participate in the process of raising awareness.

Professional nurses organizations in the United States began two decades after formal education programs were established. The first training school for nurse in the United States opened in 1873, and by 1893, nursing school administrators worked to form the American Society of Superintendents of Training Schools for Nurses (later becoming the National League for Nursing) to network, share best practices, and maintain a universal standard for training nurses (Matthews, 2012). When graduate nurses were seeking consistent standards in education and competency, they formed the Nurses Associated Alumnae of the United States and Canada (later renamed the ANA) in 1896 to elevate the standards of nursing education, establish a code of ethics, and promote the interests of nursing. Three documents developed by the ANA form the foundation of nursing as a profession and establish the role of advocacy for the professional nurse: the Code of Ethics for Nurses with Interpretive Statements (2015), Nursing: Scope and Standards of Practice (2021), and the Nursing's Social Policy Statement: The Essence of the Profession (2010). 
The director made arrangements for Linda to join the hospital's interprofessional pain committee, and she become involved in the implementation of nerve block therapy for joint replacement patients. Linda worked collaboratively with nurses from the inpatient orthopedic unit and physical therapists to assure staff knew how to safely care for the patient with a nerve block. She worked with the nursing education department to plan and implement training and developed a reference guide for staff who work infrequently with this modality. Standards of practice for pain management and other evidence-based resources were used to develop the training processes and support new policy development. Patient ratings for pain control during hospitalization improved for 10 consecutive quarters. Once this project was completed, the Pain Committee set its sights on several new projects - the use of ketamine and lidocaine infusions for patients with acute and chronic pain and the use of aromatherapy.These projects were much easier to plan and implement based on the process that was developed by Linda and the Pain Committee. Over the course of several following years, committee members presented their findings at regional and national conferences and were published in several professional journals.

Depending on the classification, there are approximately 100 national nurses associations in the United States. Most are specialty-focused, demonstrating the maturation, increased demands, and specialization that have occurred in nursing over the past 120 years. These organizations focus on missions that include legislative and broad-scale advocacy, education, professional development, and support for the professional nurse and patients' rights. These organizations with differing strategic plans have identified the value of working collaboratively on a large number of issues. Formal structures such as the Nursing Organizations Alliance (www.nursing-alliance.org) and the ANA's Organizational Affiliates (www.nursingworld.org/FunctionalMenuCategories/AboutANA/WhoWeAre/ AffiliatedOrganizations), as well as informal coalitions and groups, come together to address a specific problem or issue. See the Policy Solution for how nurses can address issues in their practice.

\section{IMPLICATIONS FOR THE FUTURE}

Advocacy at its best is about transformation. Wolf (2012) uses complexity science to demonstrate how events, patterns, and system structures can be helpful in transforming an organization. Successful nurse advocates can look beyond the events of today, see patterns and trends that are occurring, and map the direction needed for tomorrow. Future orientation causes the nurse advocate to ask: What type of care will patients look for in the future? What patterns need to change to improve the care given today? What outcomes require focus now? How might our patient population be different in future years, and what must we do to prepare for that? What structures would support that difference? What policies need to change? "The changes that are needed for patients will drive the changes that are needed for professional practice and become the source of advocacy" (Wolf, 2012, p. 309). The importance of transformational leaders to drive toward this future view of advocacy is vital. 
As nursing leaders explore the facts and observe how patterns fit together, they develop goals and objectives that will move the organization forward. They must use their influence to build collaboration and confidence, seeking staff input on how changes impact patient care, nurse satisfaction, and patient outcomes. When advocacy works best, all in the organization feel valued and engaged. Transformation in healthcare occurs only when advocacy is embraced by healthcare professionals and seen as an inherent part of their practice.

\section{KEY CONCEPTS}

1. The concept of advocacy is an integral part of professional nursing.

2. Nurses readily accept the requirement of the professional nurse's advocacy role as it applies to their patients; however, opportunities to advocate on behalf of colleagues, the profession, or even oneself are often missed.

3. The ANA Code of Ethics for Nurses with Interpretive Statements defines expectations for the professional nurse's engagement in advocacy.

4. A strong commitment to social justice requires professional nurses to advocate for health for all persons.

5. The American public sees the nurse in the role of advocate in that they have rated RNs as the most honest and ethical profession and have called for nurses to be more involved in healthcare decision-making.

6. Nurse advocates need to have the competencies of problem-solving, communication, influence, collaboration, and resource identification.

7. Advocacy works best in environments that encourage its activity, where leaders are supportive, and tools are available to make it happen.

8. Moving advocacy to the state, national, and global levels typically takes nurses from their familiar practice settings to the unfamiliar world of policy and politics, a world in which many nurses do not feel prepared to effectively maneuver.

9. Common barriers to advocacy include conflict of interest between the nurse's responsibility to the patient and duty to the employer, a lack of support, a lack of power, time constraints, threats of punishment or retaliation, or the nurse's lack of education.

10. Stress is a common workplace issue that can have serious effects. This experience can be minimized through self-advocacy measures that include mindfulness, education, a healthy lifestyle, and organizational support.

\section{SUMMARY}

As a profession, nurses "stand on the shoulders of giants" as it relates to the contributions of historical nurse leaders-championing social justice and access to care. Their contributions are still felt today. Healthcare is undergoing dramatic changes and the role of the professional nurse is evolving. In this time of evolution, nurses are in the rooms where decisions are being made. The importance of nursing advocacy and activism cannot be overstated. More than 20 million uninsured in the United States gained access to healthcare under the provisions of the ACA and until the ACA reaches its full capability, the future of care for millions of Americans remains in question. Every nurse can take active measures to foster their own voice, and collectively join together to amplify the voice of nursing to transform healthcare. Every nurse in every setting has the opportunity and responsibility to make a positive difference in the lives of patients and the quality of nursing care. Advocacy is the key. 


\section{END-OF-CHAPTER RESOURCES}

\section{LEARNING ACTIVITIES}

1. Describe two specific actions you could use to advocate for a culture of safety.

2. Describe one example of how you could infuse the Code of Ethics for Nurses into your daily practice.

3. Evaluate the resources available in your state to support nurses who have been reported to the Board of Nursing for impaired practice.

4. Explore the programs available to assist with advocacy efforts in your workplace or state. Identify three individuals you could consult to assist you with workplace concerns.

5. Identify a current issue that you have experienced or read about, and identify advocacy and/or activist strategies to promote solutions to address the issue.

6. Explore the lives and accomplishments of a historical nursing leader. What are their enduring contributions to society? Examples of nursing leaders include, but are not limited to, Dorothea Dix, Jane Delano, Lillian Wald, Mary Breckinridge, Clara Barton, Florence Nightingale, and Margaret Sanger.

\section{E-RESOURCES}

- Advocacy Project http:/ / advocacynet.org

- Agency for Healthcare Research and Quality http://www.ahrq.gov

- American Association of Nurse Practitioners State Practice Environment Map https://www.aanp.org/advocacy/state/state-practice-environment

- American Nurses Association http://www.nursingworld.org

- American Nurses Association Advocacy Toolkit, Governmental Affairs https: / / ana.aristotle.com/SitePages/toolkit.aspx

- American Nurses Association. Code of Ethics for Nurses http:/ / www. nursingworld.org/codeofethics

- American Nurses Association Policy \& Advocacy http:/ / www.nursingworld. org/MainMenuCategories/Policy-Advocacy

- American Public Health Association. Advocacy \& Policy https://www.apha. org/ /media/files/pdf/advocacy/power_of_advocacy.ashx

- Centers for Medicare \& Medicaid Services http://www.cms.gov

- Child Health Advocacy Institute https://childrensnational.org/ advocacy-and-outreach/child-health-advocacy-institute

- Commonwealth Fund http://www.commonwealthfund.org

- Department of Health and Human Services http://www.hhs.gov

- Healthy Nurse Healthy Nation https://www.healthynursehealthynation.org/

- House of Representatives http://www.house.gov

- Institute for Healthcare Improvement http://www.ihi.org

- Institute of Safe Medication Practice https://www.ismp.org

- International Council of Nurses http://www.icn.ch 
- National Academy of Medicine http://www.nam.edu

- National Conference of State Legislatures http://www.ncsl.org

- Nurse-Family Partnership NFP Nurse Advocacy Toolkit https:// www.nursefamilypartnership.org/public-policy-and-advocacy / advocacy-toolkit-for-nurses /

- Occupational Safety and Health Administration https://www.osha.gov

- Robert Wood Johnson Foundation Health Policy Fellows Program https:// www.healthpolicyfellows.org/

- Senate http://www.senate.gov

- Trust for America's Health https://www.tfah.org/

\section{REFERENCES}

American Association of Critical-Care Nurses. (2016). AACN standards for establishing and sustaining healthy work environments (2nd ed.). https://www.aacn.org/ /media/aacn-website/nursing-excellence/standards/hwestandards.pdf

American Nurses Association. (2010). Nursing's social policy statement: The essence of the profession (2nd ed.). Author.

American Nurses Association. (2015). Code of ethics for nurses with interpretive statements. https://www.nursingworld.org/practice-policy/nursing-excellence/ethics/code-of-ethicsfor-nurses/

American Nurses Association. (2017). Who will be there? Ethics, the law and nurse's duty to respond in a disaster (ANA Issue Brief). https:/ / www.nursingworld.org/ 4ad845/globalassets/docs/ ana/who-will-be-there_disaster-preparedness_2017.pdf

American Nurses Association. (2020). ANA's Membership Assembly adopts resolution on racial injustice for communities of color. https: / www.nursingworld.org/news/news-releases/2020/ ana-calls-for-racial-justice-for-communities-of-color/

American Nurses Association. (2021). Nursing: Scope and standards of practice (4th ed.). Author.

American Nurses Association \& American Association of Nurse Executives. (n.d.). Principles for collaborative relationships between clinical nurses and nurse managers. https:/ / www.nursingworld. org/ 4af4f2/globalassets/docs/ana/ethics/principles-of-collaborative-relationships.pdf

American Nurses Association Professional Issues Panel. (n.d.). A call to action: Exploring moral resilience toward a culture of ethical practice. https:/ / www.nursingworld.org/ 4907b6/globalassets/docs/ana/ana-call-to-action--exploring-moral-resilience-final.pdf

American Nurses Association. (2018). The nurses' role in addressing discrimination. Protecting and promoting inclusion, strategies in practice settings, policy and advocacy. https://www. nursingworld.org/practice-policy/nursing-excellence/official-position-statements /

Annie E. Casey Foundation. (2020). Equity vs. equality and other racial justice definitions. https:/ / www.aecf.org/blog/racial-justice-definitions/?gclid=EAIaIQobChMInZGO9ZeT7gIVIQh9Ch1Q8QPgEAAYASAAEgI-yPD_BwE

Bazdak, L., \& Turner, M. (2015). 2015 Code of Ethics for Nurses with interpretive statements: Summary of revisions to the 2001 code. American Nurse Today, 10(3), 18. https:/ / www.myamericannurse.com/

Binghamton University. (2020). Smart sharing in the age of mis and dis-information. Center for Civic Engagement. https:/ /libraryguides.binghamton.edu/c.php?g=1042510\&p=7718852

Bosek, M. S. D., \& Savage, T. A. (2007). The ethical component of nursing education: Integrating ethics into clinical experiences. Lippincott Williams \& Wilkins. 
Braveman, P., Arkin, E., Orleans, T., Proctor, D., \& Plough, A. (2017). What is health equity? And what difference does it make? http:/ / www.rwjf.org/content/dam/farm/reports/issue_ briefs / 2017/rwjf437393

Bu, X., \& Jezewski, M. A. (2007). Developing a mid-range theory of patient advocacy through concept analysis. Journal of Advanced Nursing, 57(1), 101-110. https://doi.org/10.1111/j.13652648.2006.04096.x

Butts, J. B., \& Rich, K. L. (2016). Nursing ethics: Across the curriculum and into practice (4th ed.). Jones \& Bartlett.

Cook, E. T. (1913). The life of Florence Nightingale: Vol. 1, 1820-1861. Macmillan. http:/ / www. gutenberg.org/files/40057/40057-h/40057-h.htm

Edmonson, C., McCarthy, C., Trent-Adams, S., McCain, C., \& Marshall, J. (2017, January 31). Emerging global health issues. OJIN: The Online Journal of Issues in Nursing, 22(1), 2. https://doi. org/10.3912/OJIN.Vol22No01Man02

Ersoy, N., \& Akpinar, A. (2010). Turkish nurses' decision-making in the distribution of intensive care beds. Nursing Ethics, 17(1), 87-98. https://doi.org/10.1177/0969733009349992

Florell, M. C. (2020). Concept analysis of nursing activism. Nursing Forum, 56(1), 136-140. https://doi.org/10.1111/nuf.12502

Fowler, M. D. M. (Ed.). (2015). Guide to the code of ethics with interpretive statements: Development, interpretation and application (2nd ed.). American Nurses Association.

Hanks, R. G. (2007). Barriers to nursing advocacy: A concept analysis. Nursing Forum, 42(4), 171-177. https://10.1111/j.1744-6198.2007.00084.x

Harper, K. J., \& Benson, L. S. (2019). The importance and impact of nurses serving on boards. Nursing Economic\$, 37(4), 209-212.

Healthy Nurse Healthy Nation. (2020). Healthy Nurse Healthy Nation. https:/ / www.healthynursehealthynation.org/

Hegge, M. J. (2011). The lingering presence of the Nightingale legacy. Nursing Science Quarterly, 24(2), 152-162. https://doi.org/10.1177/0894318411399453

Holt, J., Zabler, B., \& Baisch, M. (2014). Evidence-based characteristics of nurse-managed health centers for quality and outcomes. Nursing Outlook, 62(6), 428-439. https://doi.org/10.1016/j. outlook.2014.06.005

Institute of Medicine. (2011). The future of nursing: Leading change, advancing health. National Academies Press. https://doi.org/10.17226/12956

International Council of Nurses. (2021). The ICN Code of Ethics for Nurses.

https://www.icn.ch/system/files/2021-10/ICN_Code-of-Ethics_EN_Web_0.pdf

International Council of Nurses. (2021). International health care humanitarian organizations welcome the entry into force of the treaty on the prohibition of nuclear weapons. https:/ /www. icn.ch/sites/default/files/inline-files/FINAL-English-Global-Health-Statement.docx_.pdf

John F. Kennedy Presidential Library. (2021). Celebrating COVID Courage. Lauren Leander, Intensive Care Nurse, Arizona. https:/ / www.jfklibrary.org/events-and-awards/profile-in-courage-award/award-recipients/covid-courage/lauren-leander

Jurns, C. (2019). Policy advocacy motivators and barriers: Research results and applications. OJIN: The Online Journal of Issues in Nursing, 24(3). https:/ / doi.org/10.3912/OJIN. Col24No033PPT63

Khoury, C. M., Blizzard, R., Wright Moore, L., \& Hassmiller, S. (2011). Nursing leadership from bedside to boardroom: A Gallup national survey of opinion leaders. Journal of Nursing Administration, 41(7-8), 299-305. https://doi.org/10.1097/NNA.0b013e3182250a0d

Lachman, V. D. (2015). Conscientious objection in nursing: Definition and criteria for acceptance. Medsurg Nursing, 23(3), 196-198. 
Lachman, V. D., Swanson, E. O., \& Winland-Brown, J. (2015). The new "code of ethics for nurses with interpretive statements" (2015): Practical clinical application, Part II. Medsurg Nursing, 24(5), 363-366, 368. http://www.medsurgnursing.net

Lake, E. T., Sanders, J., Duan, R. Riman, K. A., Schoenauer, K. M., \& Chen, Y. (2019). A meta-analysis of the associations between the nurse work environment in hospitals and 4 sets of outcomes. Medical Care, 57(5), 353-361. https:/ / doi.org/10.1097/MLR.0000000000001109

Matthews, J. H. (2012). Role of professional organizations in advocating for the nursing profession. OJIN: The Online Journal of Issues in Nursing, 17(1), 3. https:/ / doi.org/10.3912/OJIN. Vol17No01Man03

Matwick, A. L., \& Woodgate, R. L. (2016). Social justice: A concept analysis. Public Health Nursing, 34(2), 176-184. https://doi.org/10.1111/phn.12288

McSpendon, C. (2018). World Health Organization's Chief Nursing Officer. American Journal of Nursing, 118(9), 69-70. https:/ / doi.org/10.1097/01.NAJ.0000544986.95312.c6

Navajo-Hopi Observer. (2020, November 18). Arizona nurses stand in solidarity with Navajo and Hopi neighbors in pandemic. https://www.nhonews.com/news/2020/sep/01/arizona-nurses-stand-solidarity-navajo-and-hopi-ne/?fbclid=IwAR1C48X-DQYTBLc7wdNoMi2Am4e1WCz5_DcMpU9HalkqUTTHnqaGwSZBcf4

Negarandeh, R., \& Dehghan Nayeri, N. (2012). Patient advocacy practice among Iranian nurses. Indian Medical Ethics, 9(3), 190-195. https://doi.org/10.20529/ijme.2012.063

Pagana, K. D. (2013). Ride to the top with a good elevator speech. American Nurse Today, 8(3), 14-16. https://www.myamericannurse.com/

Paquin, S. O. (2011). Social justice advocacy in nursing: What is it? How do we get there? Creative Nursing, 17(2), 63-67. https:/ / doi.org/10.1891/1078-4535.17.2.63

Pavlish, C., Brown-Saltzman, K., Hersh, M., Shirk, M., \& Rounkle, A. (2011). Nursing priorities, actions and regret for ethical situations in clinical practice. Journal of Nursing Scholarship, 43(4), 385-395. https://doi.org/10.1111/j.1547-5069.2011.01422.x

Press Ganey. (2015). Nursing special report: The influence of nurse work environment on patient, payment and nurse outcomes in acute care settings. http:/ / www.pressganey.com/about/news/ nursing-special-report-the-influence-of-nurse-work-environment-on-patient-payment-andnurse-outcomes

Rappleye, E. (2019, October 30). Nurses are most trusted to improve the US healthcare system. Becker's Hospital Review. https:/ / www.beckershospitalreview.com/hospital-management-administration/nurses-are-most-trusted-to-improve-the-us-healthcare-system.html

Ruelas, R. (2020, April 24). 'That's the one there: A photo of a protesting nurse in Phoenix goes viral.' Arizona Republic. https://www.azcentral.com/story/news/politics/arizona/2020/04/24/ how-photo-protesting-nurse-phoenix-went-viral/3023111001/

Rushton, C. (2017). Cultivating moral resilience: Shifting the narrative from powerlessness to possibility. American Journal of Nursing, 117(2 Suppl. 1), S11-S15. https://doi.org/10.1097/01. NAJ.0000512205.93596.00

Rushton, C., Schoonover, K., \& Kennedy, M. (2017). Executive summary: Transforming moral distress into moral resilience in nursing. American Journal of Nursing, 117(2), 52-56 https:/ / doi. org/10.1097/01.NAJ.0000512298.18641.31

Saad, L. (2020, December 22). U.S. Ethics Ratings rise for medical workers and teachers. https:/ / news.gallup.com/poll/328136/ethics-ratings-rise-medical-workers-teachers.aspx?version=print

Salehi, T., Dehghan Nayeri, N., \& Negarandeh, R. (2010). Ethics: Patients' rights and the code of nursing ethics in Iran. OJIN: The Online Journal of Issues in Nursing, 15(3). https: / / doi. org/10.3912/OJIN.Vol15No03EthCol01

Selanders, L., \& Crane, P. (2012). The voice of Florence Nightingale on advocacy. OJIN: The Online Journal of Issues in Nursing, 17(1), 1. https:/ / doi.org/10.3912/OJIN.Vol17No01Man01

Tomajan, K. (2012). Advocating for nurses and nursing. OJIN: The Online Journal of Issues in Nursing, 17(1), 4. https:/ /doi.org/10.3912/OJIN.Vol17No01Man04 
Vaartio, H., \& Leino-Kilpi, H. (2005). Nursing advocacy-A review of the empirical research 1990-2003. International Journal of Nursing Studies, 42(6), 282-292. https:/ /doi.org/10.1016/j. ijnurstu.2004.10.005

Vaartio, H., Leino-Kilpi, H., Salanterä, S., \& Suominen, T. (2006). Nursing advocacy: How is it defined by patients and nurses, what does it involve and how is it experienced? Scandinavian Journal of Caring Sciences, 20(3), 282-292. https:/ /doi.org/10.1111/j.1471-6712.2006.00406.x

Valderama-Wallace, C. P. (2017). Critical discourse analysis of social justice in nursing's foundational documents. Public Health Nursing, 35(1), 1-7. https:/ / doi.org/10.1111/phn.12327

Valdez, B. (2017, January). The effect of regulation on innovation in healthcare delivery. Social Innovations Journal. https:/ / socialinnovationsjournal.org/75-disruptive-innovations / 2271-the-effect-of-regulation-on-innovation-in-healthcare-delivery

Van Dyke, K., Combes, J., \& Joshi, M. (2011). AHA health care governance survey report. Center for Healthcare Governance. American Hospital Association.

White, P., Olsan, T. H., Bianchi, C., Glessner, T., \& Mapstone, P. (2010). Legislative: Searching for health policy information on the Internet: An essential advocacy skill. OJIN: The Online Journal of Issues in Nursing, 15(2). https:/ / doi.org/10.3912/OJIN.Vol15No02LegCol01

Wolf, G. (2012). Transformational leadership: The art of advocacy and influence. Journal of Nursing Administration, 42(6), 309-310. https:/ / doi.org/10.1097/NNA.0b013e3182573989 
